\title{
Forage mass, chemical composition and leaf chlorophyll index of signal grass and organic matter in soil under increasing levels of nitrogen
}

\section{Massa de forragem, composição química e índice de clorofila foliar do capim-braquiária e matéria orgânica no solo sob doses crescentes de nitrogênio}

\author{
Igor Alexandre de Souza ${ }^{1 *}$; Karina Guimarães Ribeiro ${ }^{2}$; Wellington Willian Rocha \\ Saulo Alberto do Carmo Araújo ${ }^{3}$; Odilon Gomes Pereira ${ }^{2}$; Paulo Roberto Cecon ${ }^{4}$
}

\begin{abstract}
This study evaluated the forage mass, plant height, chemical composition and chlorophyll index of signal grass (Brachiaria decumbens $\mathrm{cv}$. Basilisk), as well as the content of organic matter (OM) in soil under increasing levels of nitrogen. The experiment was conducted in the Rio Manso Farm, experimental unit of the Federal University of the Jequitinhonha and Mucuri Valleys - UFVJM in the municipality of Couto de Magalhães de Minas, state of Minas Gerais. For plant evaluation, we use a split plot randomized block design with four replications. Nitrogen levels $\left(0,25,50,75,100 \mathrm{~kg} \mathrm{ha}^{-1}\right.$ $\mathrm{N})$ were assigned to plots and the cuts made in plants, to subplots. For the assessment of soil organic matter, we used a split-split-plot, with nitrogen levels $\left(0,25,50,75\right.$ and $100 \mathrm{~kg} \mathrm{ha}^{-1}$ by cut $)$ in the plots, collection depth $(0-10$ and 10-20 cm) in the subplots and three sampling times (before the onset of the experiment, at the end of the $1^{\text {st }}$ crop year and at the end of the $2^{\text {nd }}$ crop year) in sub-subplots in a randomized block design with four replications. It can be concluded that nitrogen fertilization linearly increases forage mass, plant height and crude protein content of signal grass, which are positively correlated with chlorophyll index. At the end of two agricultural years, the content of organic matter in the soil decreases, which can be attributed to management of cutting and removal of the cut material. Key words: Height. Brachiaria decumbens. Neutral detergent fiber. Crude protein.
\end{abstract}

\section{Resumo}

Objetivaram-se avaliar a massa de forragem, a altura de plantas, a composição química e o índice de clorofila do capim-braquiária (Brachiaria decumbens cv. Basilisk), assim como, o teor de matéria orgânica (MO) no solo sob níveis crescentes de nitrogênio. O experimento foi conduzido na Fazenda Rio Manso, unidade experimental da Universidade Federal dos Vales do Jequitinhonha e Mucuri/UFVJM, na cidade de Couto de Magalhães de Minas, em Minas Gerais. Para avaliação da planta, utilizou-se o esquema de parcelas subdivididas no delineamento em blocos casualizados, com quatro repetições.

${ }^{1}$ Zootecnista, Discente de Doutorado, Universidade Estadual do Sudoeste da Bahia, UESB, Itapetinga, BA, Brasil. E-mail: igordadim@hotmail.com

${ }^{2}$ Profs., Departamento de Zootecnia, Universidade Federal de Viçosa, UFV, Viçosa, MG, Brasil. E-mail: karinaribeiro@ufv.br; odilon@ufv.br

${ }^{3}$ Profs., Departamento de Agronomia, Universidade Federal dos Vales do Jequitinhonha e Mucuri, UFVJM, Diamantina, MG, Brasil.E-mail: wwillian@ufvjm.edu.br; sauloaraujo.ufvjm@gmail.com

${ }^{4}$ Prof., Departamento de Informática, UFV, Viçosa, MG, Brasil. E-mail: cecon@ufv.br

* Author for correspondence 
Nas parcelas distribuíram-se as doses de nitrogênio $\left(0 ; 25 ; 50 ; 75 ; 100 \mathrm{~kg} \mathrm{ha}^{-1} \mathrm{de} \mathrm{N}\right)$ e nas subparcelas os cortes efetuados nas plantas. Para a avaliação da matéria orgânica do solo, utilizou-se o esquema de parcelas subsubdivididas, com as doses de nitrogênio $\left(0 ; 25 ; 50 ; 75\right.$ e $100 \mathrm{~kg} \mathrm{ha}^{-1}$ por corte) nas parcelas, profundidade de coleta $(0-10$ e 10-20 cm) nas subparcelas e os três momentos de amostragem (antes do início do experimento, ao final do $1^{\circ}$ ano agrícola e ao final do $2^{\circ}$ ano agrícola) nas subsubparcelas, no delineamento em blocos casualisados, com quatro repetições. Com base nos resultados obtidos, conclui-se que a aplicação de nitrogênio aumenta linearmente a massa de forragem, a altura de plantas e o teor de proteína bruta do capim-braquiária, os quais apresentam correlação positiva com o índice de clorofila. Ao final de dois anos agrícolas, o teor de matéria orgânica no solo decresce, o que pode ser atribuído ao manejo aplicado, de corte e remoção do material cortado.

Palavras-chave: Altura. Brachiaria decumbens. Fibra em detergente neutro. Proteína bruta.

\section{Introduction}

Nutrient availability has a strong influence on plant nutrition, which is reflected in plant development and physiological recovery (BONFIMSILVA; MONTEIRO, 2010). Among the nutrients, nitrogen is the main limiting macronutrient for pasture productivity, as it actively participates in the synthesis of organic compounds that form the structure of the plant, such as amines, amides, vitamins, pigments, amino acids, proteins, nucleic acids (MALAVOLTA, 1980).

The strategic use of nitrogen fertilizer can improve the accumulation of forage, especially in the period of increased rainfall, since the nitrogen increases the growth rate of grasses (TEIXEIRA et al., 2011). Nitrogen also has a strong influence on the nutritional value of forage, and hence on stocking rate and weight gain per animal and per hectare (VITOR et al., 2009).

Monitoring the nitrogen content of the forage plant is very important to determine the crude protein content. The relative chlorophyll index in leaves is a parameter that can be used to assess the nutritional level of nitrogen in plants, since the amount of such pigment positively correlates with the amount of this element in the plant (ARGENTA et al., 2001). In addition, nitrogen interferes directly with the photosynthetic process, given its participation in the chlorophyll molecule (MACEDO et al., 2012), increasing the photosynthetic efficiency and forage mass production.
It has been proposed the use of portable gauges, called chlorophyll meter, allowing instant readings in a non-destructive way. This reading is directly related to evaluation of nitrogen nutrition, since there is a positive correlation between the reading of leaf chlorophyll index and nitrogen concentration in grass leaves (ZOTARELLI et al., 2003).

Another factor of great importance in the study of productivity and recovery of pastures in Brazil is the content of organic matter in the soil. The stock of organic matter is a combination of processes related to the addition and loss of organic material. The main process of adding organic matter to the soil has the plant as active component, while the main process of organic material loss is the mineralization promoted by fungi and bacteria (DICK et al., 2009).

The accumulation of organic matter from appropriate soil management and crop residues is usually associated with an improvement of soil physical conditions (CAMPOS et al., 1995; ARVIDSSON, 1998). Organic matter can bring several benefits to soil structure, improving water penetration rate, lowering the pressure applied by animals, increasing porosity, aeration and water retention in the soil (BAUMGARTL; HORN, 1991).

Given the above, this study aimed to evaluate the forage mass, plant height, leaf chlorophyll index and chemical composition of a pasture of signal grass cv. Basilisk, as well as the content of organic matter in soil under increasing levels of nitrogen. 


\section{Material and Methods}

The experiment was conducted at Rio Manso farm, experimental unit of the Federal University of the Jequitinhonha and Mucuri Valleys - UFVJM, in the municipality of Couto de Magalhães de Minas, state of Minas Gerais, located at $18^{\circ} 4^{\prime} 25^{\prime \prime} \mathrm{S}$ and $43^{\circ} 28^{\prime} 16^{\prime \prime} \mathrm{W}, 756$ meters altitude. The climate is humid subtropical, Cwa, according to the climatic classification of Köppen. The annual average temperature is $23.8^{\circ} \mathrm{C}$ and the average rainfall is $1.404 \mathrm{~mm} /$ year (Table 1).

Table 1. Data of cumulative rainfall and temperature in the experimental period.

\begin{tabular}{|c|c|c|c|c|}
\hline Cut & Regrowth period & $\begin{array}{l}\text { Cumulative rainfall } \\
(\mathrm{mm})\end{array}$ & $\begin{array}{c}\text { Average maximum } \\
\text { temperature }\left({ }^{\circ} \mathrm{C}\right)\end{array}$ & $\begin{array}{l}\text { Average minimum } \\
\text { temperature }\left({ }^{\circ} \mathrm{C}\right)\end{array}$ \\
\hline $1^{\text {st }}$ & Dec $13^{\text {rd }}, 2010$ to Jan $23^{\text {rd }}, 2011$ & 326.7 & 24.5 & 16.0 \\
\hline $2^{\text {nd }}$ & Jan $24^{\text {th }}$ to March $13^{\text {rd }}, 2011$ & 350.2 & 26.8 & 16.9 \\
\hline $3^{\text {rd }}$ & Dec $09^{\text {th }}, 2011$ to Jan $16^{\text {th }}, 2012$ & 532.1 & 23.6 & 16.2 \\
\hline $4^{\text {th }}$ & Jan $17^{\text {th }}$ to Feb $27^{\text {th }}, 2012$ & 99.0 & 25.7 & 16.0 \\
\hline
\end{tabular}

Source: National Institute of Meteorology INMET, Diamantina, state of Minas Gerais.

Physical and chemical analyses of soil were performed in the layers of $0-10$ and $10-20 \mathrm{~cm}$ for due characterization (Table 2). The soil was classified as Dystrophic Red-Yellow Latosol, clayey, deep, with little differentiation between horizons, for being quite weathered, with low natural fertility, gently undulating relief, with slope between 3 and $6 \%$ (EMBRAPA, 2006).

Table 2. Chemical and physical characteristics of soil samples taken at 0-10 and 10-20 cm depth layers, Laboratory of Soil fertility and Physics/ UFVJM.

\begin{tabular}{|c|c|c|c|c|c|c|c|c|c|c|c|c|c|}
\hline Depth & $\mathrm{pH}$ & $\mathrm{H}+\mathrm{Al}$ & $\mathrm{Al}$ & $\mathrm{Ca}$ & $\mathrm{Mg}$ & $\mathrm{K}$ & $\mathrm{P}$ & $\mathrm{OM}$ & $\mathrm{V}$ & $\mathrm{M}$ & SB & $\mathrm{t}$ & $\mathrm{T}$ \\
\hline$-\mathrm{cm}-$ & & \multicolumn{4}{|c|}{------ cmolc dm-3 ----- } & \multicolumn{2}{|c|}{$\mathrm{mg} \mathrm{dm}{ }^{-3}$} & Dag kg ${ }^{-1}$ & \multicolumn{2}{|c|}{$--\%$-- } & \multicolumn{3}{|c|}{---- cmolc dm dm $^{-3}---$} \\
\hline $0-10$ & 5.4 & 7.3 & 0.5 & 1.34 & 0.48 & 49 & 1.63 & 1.9 & 21 & 20 & 1.95 & 2.45 & 9.25 \\
\hline $10-20$ & 5.5 & 6.5 & 0.4 & 1.02 & 0.60 & 30 & 1.03 & 1.3 & 21 & 19 & 1.7 & 2.10 & 8.2 \\
\hline Depth & Sand & Silt & \multicolumn{3}{|c|}{ Clay } & & & & & & & & \\
\hline$-\mathrm{cm}-$ & \multicolumn{5}{|c|}{ |------------ \% ----------------- } & & & & & & & & \\
\hline $0-10$ & 43 & 15 & \multicolumn{2}{|c|}{42} & & & & & & & & & \\
\hline $10-20$ & 43 & 13 & \multicolumn{2}{|c|}{44} & & & & & & & & & \\
\hline
\end{tabular}

$\mathrm{pH}$ in water - Ratio $1: 2.5 ; \mathrm{H}+\mathrm{Al}$ - Calcium Acetate extractor $0.5 \mathrm{~mol} / \mathrm{L} ; \mathrm{Al}, \mathrm{Ca}$ and $\mathrm{Mg}$ - Extractor $\mathrm{KCl} 1 \mathrm{~mol} / \mathrm{L} ; \mathrm{K}$ and $\mathrm{P}$ - Extrator Extractor -1; OM. - Organic matter = C. org x 1.724; V - Base saturation; m Aluminum saturation; SB sum of bases; $t$ effective cation exchange capacity; $\mathrm{T}$ cation exchange capacity at $\mathrm{pH}$ 7.0.

The experiment was established on degraded pasture (Brachiaria decumbens cv. Basilisk), formed about ten years ago and that had low forage mass production and considerable weed infestation. The pasture over that time was managed without grazing pressure control and no fertilization.

In a representative area of the pasture, we delimited four blocks spaced 2 meters apart, and each block was divided into five plots, totaling 20 experimental units. The whole area was fenced 
to prevent invasion by animals grazing in the surroundings. Weed control was carried out by manual weeding.

For the variables related to the plant, data were analyzed in a split-plot arrangement, including $1 / 3$ of total nitrogen levels $\left(0 ; 25 ; 50 ; 75\right.$ and $100 \mathrm{~kg} \mathrm{ha}^{-1}$ per cut) in the plots and cuts in subplots in time, in a randomized block design with four replications. Four cuts were used to evaluate the forage mass (FM), content of crude protein (CP) and neutral detergent fiber (NDF); three cuts to evaluate the plant height and two cuts to evaluate the leaf chlorophyll content.

On December $13^{\text {th }}, 2010$, in the first agricultural year, it was held the uniformity cut of plants in all plots to the height of $10 \mathrm{~cm}$ from ground level, with a motorized backpack brush cutter. The cut material was removed from the area with the aid of a rake, and then fertilization was carried out with $100 \mathrm{~kg}$ ha $^{-1} \mathrm{P}_{2} \mathrm{O}_{5}$ and $75 \mathrm{~kg} \mathrm{ha}^{-1} \mathrm{~K}_{2} \mathrm{O}$, in all plots, based on the chemical analysis of the soil along with $1 / 3$ of total nitrogen levels according to the treatments $\left(0 ; 25 ; 50 ; 75\right.$ and $100 \mathrm{~kg} \mathrm{ha}^{-1}$ per cut), using single superphosphate, potassium chloride and ammonium sulfate, respectively.

On January $24^{\text {th }}$ 2011, the first cut was done in plants and reapplied the levels of nitrogen, along with $75 \mathrm{~kg} \mathrm{ha}^{-1} \mathrm{~K}_{2} \mathrm{O}$; on March $14^{\text {th }}, 2011$, the second cut was made in plants and reapplied nitrogen and potassium, and, on April 30 $0^{\text {th }}$, 2014, the third cut was done in plants without fertilization. After all the cuts, the material was removed from the plots. In this year, samples of the third cut were not evaluated.

On October 31 $31^{\text {st }}, 2011$, the second agricultural year, the uniformity cut was performed in plants of all plots as in the first agricultural year. The first cut was made on December $08^{\text {th }}, 2011$ the second, on January $16^{\text {th }}, 2012$ and the third, on February $27^{\text {th }}$, 2012. Fertilization management was the same as in the first year. After all the cuts, the material was removed from the plots. In this year, samples of the first cut were not evaluated.
For forage sampling, we used a frame made of PVC pipes with an area of $1.0 \mathrm{~m}^{2}$, placed at the center of each plot, in which, plants were manually cut with a cleaver, at a height of $10 \mathrm{~cm}$ from ground level. Before the cuts, heights of the plants were recorded in the $2^{\text {nd }}, 3^{\text {rd }}$ and $4^{\text {th }}$ cuts, and chlorophyll index was measured in plant leaves, in the $3^{\text {rd }}$ and $4^{\text {th }}$ cuts.

For height measurement, we used a metal measuring tape to take three measurements from the base to the horizon of curvature of the leaves in each plot. To estimate the chlorophyll index, we used a portable chlorophyll meter, model ClorofiLOG ${ }^{\circledR}$ CFL 1030, operated according to manufacturer's instructions (FALKER, 2008). Total chlorophyll (a $+b$ ) indexs were determined in the middle third of fully expanded leaves, taking three measurements on each leaf, to obtain an average value. These measurements were performed in 10 leaves/plot at random, calculating the averages. In this equipment, the measurement units are called Falker Chlorophyll Index (FCI).

For measuring the forage mass, samples were placed in bags and sent to the Forage Laboratory of the Federal University of the Jequitinhonha e Mucuri Valleys - UFVJM, where they were weighed. Then, representative forage samples were taken from each treatment, weighed and oven-dried under forced air circulation at $55^{\circ} \mathrm{C}$ to constant weight, and then weighed and ground in a Wiley mill with a sieve of $1 \mathrm{~mm}$, and stored in sealed plastic containers, for analysis of chemical composition. Next, subsamples were taken for analysis of dry matter (DM), crude protein (CP) and neutral detergent fiber (NDF), following the methodology described by Detmann et al. (2012).

For the assessment of soil organic matter, we used a split split plot arrangement, with nitrogen levels $\left(0 ; 25 ; 50 ; 75\right.$ and $100 \mathrm{~kg} \mathrm{ha}^{-1}$ per cut) assigned to plots, depth layers $(0-10$ and $10-20 \mathrm{~cm})$ to subplots and the three sample times, before the onset of the experiment $\left(\operatorname{Dec} 10^{\text {th }}, 2010\right)$, at the end of the $1^{\text {st }}$ 
year (May 14 ${ }^{\text {th }}$ 2011) and at the end of the $2^{\text {nd }}$ year (March 03 ${ }^{\text {rd }}$ 2012) to sub-subplots, in a randomized block design with four replications.

Samples for OM analysis were collected with the aid of a cutting spade, two samples in each of 20 plots, one at a depth of 0-10 cm and another at 10$20 \mathrm{~cm}$, totaling 40 samples per collection. Samples were analyzed by the colorimetric method described by RAIJ et al. (2001).

Data were subjected to analysis of variance and regression analysis. For qualitative variables, we used the Tukey's test and F-test and for quantitative variables, we applied regression analysis, at 5\% probability, using the statistical software SAEG 9.1 (SAEG-UFV, 2007).

\section{Results and Discussion}

There was no effect of the interaction between nitrogen levels and cuts for forage mass (FM), but rather independent effects of cuts and nitrogen levels for this variable (Tables 3 and 4). There was an increase of $60 \%$ in forage mass produced in the last cut compared to the first cut. The FM of signal grass also responded positively and linearly to levels of nitrogen fertilizer, ranging from 1,394 to $2,599 \mathrm{~kg} \mathrm{ha}^{-1}$ cut at the levels of 0 and $100 \mathrm{~kg}$ $\mathrm{ha}^{-1}$ per cut, respectively. Similarly, Viana et al. (2011) investigated the influence of 0, 100, 200 and $300 \mathrm{~kg} \mathrm{ha}^{-1}$ nitrogen in the rainy season on signal grass pasture (Brachiaria decumbens cv. Basilisk) and reported $56 \%$ increase in forage mass with the maximum level used.

For plant height, no effect of the interaction between nitrogen levels and cuts was detected, but rather independent effects of cuts and nitrogen. Table 3 shows that in the third and fourth cuts, in the second year of the study, plant height exceeded the average height recommended for $95 \%$ radiation interception, which is $25 \mathrm{~cm}$, according to Silva et al. (2008), which can be attributed to residual effect of nitrogen and greater rainfall recorded (Table 1), especially in the third cut, because the plants were harvested at the same age.

Table 3. Forage mass (FM), plant height and dry matter content (DM) of Brachiaria decumbens cv. Basilisk, per cut (average of five nitrogen levels).

\begin{tabular}{lcccc}
\hline & \multicolumn{3}{c}{ Cut $/$ Year } \\
\cline { 2 - 5 } & $1^{\text {st }} / 2011$ & $2^{\text {nd }} / 2011$ & $3^{\text {rd }} / 2012$ & $4^{\text {th }} / 2012$ \\
\hline FM $\left(\mathrm{kgha}^{-1}\right)$ & $1789.14 \mathrm{c}$ & $940.68 \mathrm{~d}$ & $2382.13 \mathrm{~b}$ & $2875.67 \mathrm{a}$ \\
Height $(\mathrm{cm})$ & $\mathrm{NA}$ & $21.41 \mathrm{c}$ & $33.46 \mathrm{a}$ & $28.76 \mathrm{~b}$ \\
DM $(\%)$ & $24.40 \mathrm{a}$ & $17.39 \mathrm{c}$ & $20.10 \mathrm{~b}$ & $24.13 \mathrm{a}$ \\
\hline
\end{tabular}

$\mathrm{NA}=$ non-evaluated; cut $1=\operatorname{Jan} 24^{\text {th }} 2011$; cut $2=$ March $14^{\text {th }} 2011$; cut $3=\operatorname{Jan} 16^{\text {th }} 2012$ ad cut $4=$ March $21^{\text {st }} 2012$. Means followed by different letters in the same row are significantly different by Tukey's test at $1 \%$ probability.

With the increase of nitrogen levels, plant height varied between $22.1 \mathrm{~cm}$, in the absence of nitrogen fertilizer, and $33.67 \mathrm{~cm}$ in plants that received the highest level of nitrogen $\left(100 \mathrm{~kg} \mathrm{ha}^{-1}\right.$ per cut) (Table 4). These results are consistent with increased forage mass as a function of nitrogen levels.
In an experiment evaluating height of signal grass plants (Brachiaria decumbens cv Basilisk.) in three periods of deferment (73, 95 and 116 days) and four nitrogen levels $\left(0,40,80\right.$ and $\left.120 \mathrm{~kg} \mathrm{ha}^{-1}\right)$, Santos et al. (2009) observed height values ranging from 23 to $73 \mathrm{~cm}$, for the shorter period, in the absence of nitrogen, and the longer period, with the highest level of nitrogen, respectively. 
Table 4. Forage mass (FM), plant height and leaf chlorophyll index of Brachiaria decumbens cv. Basilisk fertilized with increasing levels of nitrogen $(0 ; 25 ; 50 ; 75$ and $100 \mathrm{~kg}$ ha-1 per cut), respective regression equations, coefficients of determination $\left(\mathrm{r}^{2}\right)$ and coefficients of variation $(\mathrm{CV})$.

\begin{tabular}{|c|c|c|c|c|c|c|}
\hline \multicolumn{5}{|c|}{$\mathrm{N}\left(\mathrm{kg} \mathrm{ha}^{-1}\right)$} & \multirow[t]{2}{*}{$r^{2}$} & \multirow[t]{2}{*}{$\mathrm{CV}(\%)$} \\
\hline 0 & 25 & 50 & 75 & 100 & & \\
\hline \multicolumn{7}{|c|}{ FM (kg ha-1 per cut) } \\
\hline 1.297 .0 & 1.721 .3 & 2.141 .8 & 2.319 .2 & 2.504 .9 & & \\
\hline \multicolumn{5}{|c|}{$\hat{\mathrm{Y}}=1394.17+12.0547^{* *} \mathrm{~N}$} & 0.96 & 26.4 \\
\hline \multicolumn{7}{|c|}{ Plant height $(\mathrm{cm})$} \\
\hline 20.89 & 24.62 & 30.32 & 31.89 & 35.20 & & \\
\hline \multicolumn{5}{|c|}{$\hat{\mathrm{Y}}=22.1047+0.115507^{* *} \mathrm{~N}$} & 0.89 & 20.62 \\
\hline \multicolumn{7}{|c|}{ Leaf chlorophyll index } \\
\hline 35.26 & 37.65 & 40.60 & 42.7 & 49.1 & & \\
\hline \multicolumn{5}{|c|}{$\hat{\mathrm{Y}}=34.5125+0.13101^{* *} \mathrm{~N}$} & 0.95 & 6.28 \\
\hline \multicolumn{7}{|c|}{$\mathrm{DM}(\%)$} \\
\hline 23.29 & 22.09 & 21.43 & 20.34 & 20.38 & & \\
\hline \multicolumn{5}{|c|}{$\hat{\mathrm{Y}}=23.015-0.0301993^{* *} \mathrm{~N}$} & 0.93 & 4.77 \\
\hline
\end{tabular}

Chlorophyll index values (FCI) were not affected by the interaction between nitrogen levels and cuts, as well as there was no independent effect of cuts, only nitrogen levels (Table 4). Thus, FCI varied from 34.51 to 47.61 , increasing linearly and positively with the levels of nitrogen, from 0 to $100 \mathrm{~kg} \mathrm{ha}^{-1}$ per cut, respectively. Reading the chlorophyll index can optimize the management of pastures, allowing an instant estimate of crude protein content, and indicates the nutritional status of forage grasses. Silveira (2009) employed equipment similar to that used herein and noticed an FCI values range of 27-44, using nitrogen levels of 0-100 kg ha-1 per cut, in Brachiaria decumbens.

The dry matter content of plants was not influenced by the interaction between nitrogen levels and cuts, but was affected by nitrogen levels and the cuts separately (Tables 3 and 4). In the analysis of DM per cut, DM content values were higher in the $1^{\text {st }}$ and $4^{\text {th }}$ cuts, close to $24 \%$, while in the $2^{\text {nd }}$ cut, we observed the lowest DM content (17.4\%). The dry matter content ranged from 23 to
$20 \% \mathrm{DM}$, with levels varying between 0 and $100 \mathrm{~kg}$ $\mathrm{ha}^{-1}$ per cut, respectively, consistent with increasing levels of nitrogen fertilizer.

There was a significant interaction between nitrogen levels and cuts for crude protein, whose results are listed in Table 5. In general, the crude protein content increased linearly in response to increasing levels of nitrogen, ranging from $5.74 \%\left(4^{\text {th }} \mathrm{cut}\right)$ to $16.59 \%$ ( $\left.2^{\text {nd }} \mathrm{cut}\right)$, respectively, with increasing levels of nitrogen from 0 to 100 $\mathrm{kg} \mathrm{ha}^{-1}$ per cut. There were much higher values of CP in the $2^{\text {nd }}$ cut than in the other cuts, which can be attributed to lower forage mass (940.680 $\mathrm{kg} \mathrm{ha}^{-1}$ ), due to a water stress for 29 days, which contributed to increased crude protein content. In the $4^{\text {th }}$ cut, the crude protein content of unfertilized plants was quite below the lower limit of $7 \%$, recommended by the NRC (1996), to meet the minimum requirements of rumen microorganisms, indicating worse chemical composition in plants not fertilized with nitrogen. 
Table 5. Crude protein content of Brachiaria decumbens $\mathrm{cv}$. Basilisk fertilized with increasing nitrogen levels $(0 ; 25$; $50 ; 75$ and $\left.100 \mathrm{~kg} \mathrm{ha}^{-1}\right)$, in four cuts, respective regression equations and coefficients of determination $\left(\mathrm{r}^{2}\right)($ Coefficient of variation $=7.45 \%$ ).

\begin{tabular}{|c|c|c|c|c|c|c|}
\hline \multirow[t]{2}{*}{ Cut/Year } & \multicolumn{5}{|c|}{$\mathrm{N}\left(\mathrm{kg} \mathrm{ha}^{-1}\right)$} & \multirow[t]{2}{*}{$r^{2}$} \\
\hline & 0 & 25 & 50 & 75 & 100 & \\
\hline \multicolumn{7}{|c|}{ Crude protein $(\% \mathrm{DM})$} \\
\hline \multirow[t]{2}{*}{$1^{\mathrm{st} / 2011}$} & 7.88 & 8.07 & 8.72 & 9.39 & 10.48 & \\
\hline & \multicolumn{5}{|c|}{$\hat{\mathrm{Y}}=7.60962+0.0259958^{* *} \mathrm{~N}$} & 0.94 \\
\hline \multirow[t]{2}{*}{$2^{\text {nd } / 2011}$} & 11.25 & 12.06 & 14.26 & 15.33 & 16.43 & \\
\hline & \multicolumn{5}{|c|}{$\hat{\mathrm{Y}}=11.1349+0.05461^{* *} \mathrm{~N}$} & 0.98 \\
\hline \multirow[t]{2}{*}{$3^{\text {rd }} / 2012$} & 9.47 & 8.06 & 9.46 & 10.40 & 10.93 & \\
\hline & \multicolumn{5}{|c|}{$\hat{\mathrm{Y}}=8.6102+0.02107^{* *} \mathrm{~N}$} & 0.58 \\
\hline \multirow[t]{2}{*}{$4^{\text {th }} / 2012$} & 6.34 & 6.13 & 8.66 & 9.89 & 11.25 & \\
\hline & \multicolumn{5}{|c|}{$\hat{\mathrm{Y}}=5.74134+0.0542711^{* *} \mathrm{~N}$} & 0.93 \\
\hline
\end{tabular}

${ }^{* *} 1 \%$ probability level.

Regarding the neutral detergent fiber content (NDF), there was effect of the interaction between nitrogen and cuts, however, the data obtained in the $1^{\text {st }}, 3^{\text {rd }}$ and $4^{\text {th }}$ cuts did not fit to any regression equation to explain the biological phenomenon, whose mean values of treatments were $70.7 ; 71.2$ and $71.7 \%$, respectively (Table 6 ). In the $2^{\text {nd }}$ cut,
NDF values were estimated as varying from 62.8 and $59.5 \%$ in the absence of nitrogen and the maximum level, respectively. These values are relatively lower than those obtained in other cuts, which can be explained by climatic limitation during regrowth of plants, which grew more slowly and have not reached physiological maturity.

Table 6. Neutral detergent fiber content of Brachiaria decumbens cv. Basilisk fertilized with increasing nitrogen levels $\left(0 ; 25 ; 50 ; 75\right.$ and $\left.100 \mathrm{~kg} \mathrm{ha}^{-1}\right)$, in four cuts, regression equation and coefficient of determination $\left(\mathrm{r}^{2}\right)$ (coefficient of variation $=2.25 \%$ ).

\begin{tabular}{|c|c|c|c|c|c|c|}
\hline \multirow[t]{2}{*}{ Cut } & \multicolumn{5}{|c|}{$\mathrm{N}\left(\mathrm{kg} \mathrm{ha}^{-1}\right)$} & \multirow[t]{2}{*}{$\mathrm{r}^{2}$} \\
\hline & 0 & 25 & 50 & 75 & 100 & \\
\hline \multicolumn{7}{|c|}{ Neutral detergent fiber $(\% \mathrm{DM})$} \\
\hline \multirow[t]{2}{*}{$1 \% / 2011$} & 70.99 & 70.39 & 70.86 & 70.96 & 70.52 & \\
\hline & & & Mean $=70$ & & & - \\
\hline \multirow[t]{2}{*}{$2^{\circ} / 2011$} & 63.10 & 62.24 & 59.98 & 60.68 & 59.80 & \\
\hline & \multicolumn{5}{|c|}{$\hat{\mathrm{Y}}=62.7924-0.0326289^{* *} \mathrm{~N}$} & 0.79 \\
\hline \multirow[t]{2}{*}{ 3\%/2012 } & 70.38 & 69.55 & 72.01 & 73.87 & 70.06 & \\
\hline & & & Mean $=71$ & & & - \\
\hline \multirow[t]{2}{*}{$4 \% / 2012$} & 71.53 & 71.33 & 72.46 & 69.28 & 74.09 & \\
\hline & & & Mean $=71$ & & & - \\
\hline
\end{tabular}

${ }^{* *} 1 \%$ probability level. OBS.: Equations obtained for cuts 1, 3 and 4 showed no good fit to the data, choosing the mean of treatments

Correlations were tested between all the shows significant correlations between the Falker variables studied and chlorophyll index. Table 7 chlorophyll index and forage mass $(\mathrm{r}=0.54)$, plant 
height $(\mathrm{r}=0.66)$ and crude protein content $(\mathrm{r}=$ 0.63 ), which is explained by the close relationship of chlorophyll content, and hence, the photosynthetic activity, with the nitrogen content in leaf biomass (BLACKBURN, 2007).

Table 7. Correlation between leaf Falker Chlorophyll Index (FCI) and forage mass (FM), plant height and crude protein content $(\mathrm{CP})$ in signal grass (Brachiaria decumbens).

\begin{tabular}{cccc}
\hline & FCI x FM & FCI x height & FCI x CP \\
\hline Correlation & 0.5411 & 0.6613 & 0.6392 \\
\hline
\end{tabular}

The linear increase in protein content with increasing nitrogen levels, in all cuts, supports the estimation analysis of chlorophyll index through portable equipment. Maranhão et al. (2009) observed linear correlation $(r=0.96)$ between the chlorophyll values and crude protein content in two cultivars of signal grass (Brachiaria brizantha $\mathrm{cv}$. Marandu and B. decumbens cv. Basilisk), fertilized with annual levels of $0 ; 50 ; 100$ and $150 \mathrm{~kg} \mathrm{ha}^{-1} \mathrm{~N}$ per cut. Moreover, Costa et al. (2012) found that levels of 0, 50, 100, 150 and $200 \mathrm{~kg} \mathrm{ha}^{-1} \mathrm{~N}$ applied to Brachiaria brizantha cv. Xaraés and Brachiaria ruziziensis influenced the FCI values, which were positively correlated $(\mathrm{r}=0.75)$ with crude protein content. Silva et al. (2011) found that chlorophyll index values were correlated $(r=0.95)$ with the total chlorophyll content extracted from leaf blades of forages, and chlorophyll index close to 30 were related to protein content $\leq 7 \%$. In this sense, Brachiaria showed chlorophyll content above the critical, regardless of the level of nitrogen fertilizer.

The levels of organic matter (OM) in the soil were influenced by the three factors studied (Tables 8 and 9). In general, OM content between depths did not change or was higher at smaller depth $(0-10 \mathrm{~cm})$. At the end of the second year, the organic matter content was reduced in both depths and for all nitrogen fertilizer levels. As the grazing was stopped in the study area and that all the cut material was removed from the area, litter accumulation on the soil was reduced, which consequently may have contributed to the decrease in soil organic matter.

Table 8. Organic matter content (dag kg-1) in five nitrogen levels $\left(0 ; 25 ; 50 ; 75\right.$ and $100 \mathrm{~kg} \mathrm{ha}^{-1}$ per cut), at two soil depths P1 $(0-10 \mathrm{~cm})$ and $\mathrm{P} 2(10-20 \mathrm{~cm})$ and in three sampling times.

\begin{tabular}{|c|c|c|c|c|c|c|}
\hline \multirow[b]{2}{*}{ Times } & \multicolumn{2}{|c|}{$\mathrm{N} 0 \mathrm{~kg} \mathrm{ha}^{-1}$ cut } & \multicolumn{2}{|c|}{$\mathrm{N} 25 \mathrm{~kg} \mathrm{ha}^{-1}$ cut } & \multicolumn{2}{|c|}{ N $50 \mathrm{~kg} \mathrm{ha}^{-1}$ cut } \\
\hline & P1 & P2 & P1 & P2 & P1 & P2 \\
\hline M1 & $2.2 \mathrm{Aa}$ & $1.8 \mathrm{Aa}$ & $2.57 \mathrm{Aa}$ & $1.67 \mathrm{Ab}$ & $2.62 \mathrm{Aa}$ & $1.65 \mathrm{Ab}$ \\
\hline M2 & $2.3 \mathrm{Aa}$ & $1.32 \mathrm{Ab}$ & $1.82 \mathrm{Ba}$ & $1.52 \mathrm{Aa}$ & $1.55 \mathrm{Ba}$ & $1.62 \mathrm{Aa}$ \\
\hline \multirow[t]{3}{*}{ M3 } & $0.72 \mathrm{Ba}$ & $0.55 \mathrm{Ba}$ & $0.85 \mathrm{Ca}$ & $0.60 \mathrm{Ba}$ & $0.95 \mathrm{Ca}$ & $0.75 \mathrm{Ba}$ \\
\hline & \multicolumn{2}{|c|}{$\mathrm{N} 75 \mathrm{~kg} \mathrm{ha}^{-1}$ cut } & \multicolumn{2}{|c|}{ N $100 \mathrm{~kg} \mathrm{ha}^{-1}$ cut } & & \\
\hline & P1 & P2 & P1 & $\mathrm{P} 2$ & & \\
\hline M1 & 2.10Aa & $1.67 \mathrm{Aa}$ & $2.45 \mathrm{Aa}$ & $1.82 \mathrm{Aa}$ & & \\
\hline M2 & $1.75 \mathrm{Aa}$ & $1.32 \mathrm{Aa}$ & $2.15 \mathrm{Aa}$ & $1.35 \mathrm{ABb}$ & & \\
\hline M3 & $0.97 \mathrm{Ba}$ & $0.62 \mathrm{Ba}$ & $1.07 \mathrm{Ba}$ & $0.92 \mathrm{Ba}$ & & \\
\hline
\end{tabular}

Different lower case letters in the same row indicate significant differences by F-test and different upper case letters in the same column indicate significant differences by Tukey's test at $5 \%$ probability level.

$\mathrm{N}=$ nitrogen; $\mathrm{M} 1=$ time of collection before treatments; $\mathrm{M} 2=$ time of collection at the end of the first year; $\mathrm{M} 3=$ time of collection at the end of the second year. 
In Table 9, the behavior of OM content according to nitrogen levels was not consistent. In the depth of $0-10 \mathrm{~cm}$, the $\mathrm{OM}$ content presented a quadratic effect and reached a minimum of 1.60 dag $\mathrm{kg}^{-1}$ soil at a level of $50 \mathrm{~kg} \mathrm{ha}^{-1} \mathrm{~N}$ per cut, at the end of the first year (M2), while at the end of the second year (M3) it showed a positive linear effect and the values varied between 0.75 and $1.08 \mathrm{dag} \mathrm{kg}^{-1}$ soil at levels from 0 to $100 \mathrm{~kg} \mathrm{ha}^{-1} \mathrm{~N}$ per cut, respectively. In the 10-20 cm depth, we found a square root fit at the end of the first year (M2) and the minimum content of OM was $1.31 \mathrm{~kg} \mathrm{dag}^{-1}$ soil with $100 \mathrm{~kg}$ $\mathrm{ha}^{-1} \mathrm{~N}$ per cut; at the end of the second year (M3), we observed a positive linear effect, ranging from 0.75 to 1.08 dag $\mathrm{kg}^{-1}$ soil for levels of $0-100 \mathrm{~kg} \mathrm{ha}^{-1}$ $\mathrm{N}$ per cut.

Table 9. Regression equations of organic matter $\left(\mathrm{dag} \mathrm{kg}^{-1}\right)$ according to five levels of nitrogen $(0 ; 25 ; 50 ; 75$ and 100 $\left.\mathrm{kg} \mathrm{ha}^{-1} \mathrm{cut}\right)$, at two soil depth layers $(0-10 \mathrm{~cm}$ and $10-20 \mathrm{~cm})$ and in three sampling times.

\begin{tabular}{ccc}
\hline Time & Equations fit & $\mathrm{r}^{2} / \mathrm{R}^{2}$ \\
\hline & Depth $=0-10 \mathrm{~cm}$ & \\
\hline M1 & $\mathrm{Y}=2.17571+0.0416429 \mathrm{~N}-0.0010314 \mathrm{~N}^{2}+0.0000064 \mathrm{~N}^{3}$ & 0.81 \\
M2 & $\mathrm{Y}=2.30786-0.0269286 \mathrm{~N}+0.000254286 \mathrm{~N}^{2}$ & 0.99 \\
M3 & $\mathrm{Y}=0.75+0.0033 \mathrm{~N}$ & 0.96 \\
\hline & Depth $=10-20 \mathrm{~cm}$ & 0.99 \\
M1 & $\mathrm{Y}=1.80071-0.00665714 \mathrm{~N}+0.0000685714 \mathrm{~N}^{2}$ & 0.67 \\
M2 & $\mathrm{Y}=1.32249+0.0972343 \mathrm{~N}^{1 / 2}-0.00980236 \mathrm{~N}$ & 0.66 \\
\hline
\end{tabular}

$\mathrm{N}=$ nitrogen; $\mathrm{M} 1=$ time of collection before treatments; $\mathrm{M} 2=$ time of collection at the end of the first year; $\mathrm{M} 3=$ time of collection at the end of the second year.

\section{Conclusions}

Nitrogen fertilization linearly increases the forage mass, plant height, dry matter content and chlorophyll index of signal grass. Leaf chlorophyll index is positively correlated with forage mass, plant height and crude protein content. At the end of two growing seasons, the content of organic matter in the soil decreases, which can be attributed to management of cutting and removal of the cut material.

\section{References}

ARGENTA, G.; SILVA, P. D.; BORTOLINI, C. G.; FORSTHOFER, E.L.; STRIEDER, M. L. Relação da leitura do clorofilômetro com os teores de clorofila extraível e de nitrogênio na folha de milho. Revista Brasileira de Fisiologia Vegetal, Brasília, v. 13, n. 2, p. 158-167, 2001.
ARVIDSSON, J. Influence of soil texture and organic matter content on bulk density, air content, compression index and crop yield in field and laboratory experiments. Soil \& Tillage Research, Amsterdam v. 49, n. 1, p. 159170, 1998.

BAUMGARTL, T.; HORN, R. Effect of aggregate stability on soil compaction. Soil\& Tillage Research, Amsterdam, v. 19, n. 2, p. 203-213, 1991.

BLACKBURN, G. A. Hyperspectral remote sensing of plant pigments. Journal of Experimental Botany, Lancaster, v. 58, n. 4, p. 855-867, 2007.

BONFIM-SILVA, E. M.; MONTEIRO, F. A. Nitrogênio e enxofre na adubação e em folhas diagnósticas e raízes do capim-braquiária em degradação. Revista Brasileira de Zootecnia, Viçosa MG, v. 39, n. 8, p. 1641-1649, 2010.

CAMPOS, B. C.; REINERT, D. J.; NICOLODI, R.; RUEDELL, J.; PETRERE, C. Estabilidade estrutural de um Latossolo Vermelho-Escuro distrófico após sete anos de rotação de culturas e sistemas de manejo de solo. Revista Brasileira de Ciência do Solo, Viçosa, MG, v. 19, n. 1, p. 121-126, 1995. 
COSTA, N. R.; ANDREOTTI, M.; GAMEIRO, R. A.; PARIZ, C. M.; BUZETTI, S.; LOPES, K. S. M. Adubação nitrogenada no consórcio de milho com duas espécies de braquiária em sistema plantio direto. Pesquisa Agropecuária Brasileira, Brasília, v. 47, n. 9, p. 1038-1047, 2012.

DETMANN, E.; SOUZA, M. A.; VALADARES FILHO, S. C.; QUEIROZ, A. C.; BERCHIELLI, T. T.; SALIBA, E. O. S.; CABRAL, L. S.; PINA, D. S.; LADEIRA, M. M.; AZEVEDO, J. A. G. Métodos para análise de alimentos. Instituto Nacional de Ciência e Tecnologia de Ciência Animal. Visconde do Rio Branco: Suprema, 2012. $214 \mathrm{p}$.

DICK, D. P.; NOVOTNY, E. H.; DIECKOW, J.; BAYER, C. Química da matéria orgânica do solo. In: MELO, V. F.; ALLEONI, L. R. F. Química e mineralogia do solo. Viçosa, MG: Sociedade Brasileira de Ciência do Solo, 2009. Parte 2, p. 1-68.

EMPRESA BRASILEIRA DE PESQUISA AGROPECUÁRIA - EMBRAPA. Centro Nacional de Pesquisa de Solos. Sistema brasileiro de classificação de solos. 2. ed. Rio de Janeiro: Embrapa Solos, 2006. $306 \mathrm{p}$.

FALKER AUTOMAÇÃO AGRÍCOLA Ltda. Manual do medidor eletrônico de teorclorofila (ClorofiLOG / CFL 1030). Porto Alegre: Falker Automação Agrícola, 2008. $33 \mathrm{p}$.

MACEDO, C. H. O.; ANDRADE, A. P.; SANTOS, E. M.; SILVA, D. S.; SILVA, T. C.; EDVAN, R. L. Perfil fermentativo e composição bromatológica de silagens de sorgo em funcao da adubação nitrogenada. Revista Brasileira de Saúde e Produção Animal, Salvador, v. 13, n. 2, p. 371-382, 2012.

MALAVOLTA, E. Elementos de nutrição mineral de plantas. São Paulo: Agronômica Ceres, 1980. 251 p.

MARANHÃO, C. M. A.; SILVA C. C. F. da; BONOMO, P.; PIRES, A. J. V. Produção e composição quimicobromatologica de duas cultivares de braquiária adubadas com nitrogênio e sua relação com o índice SPAD. Acta Scientiarum, Maringá, v. 31, n. 2, p. 117-122, 2009.

NATIONAL RESEARCH COUNCIL - NRC. Nutrients requeriments of beef cattle. 7. ed. Washington, D.C: NRC, 1996. 232 p.

RAIJ, B.; ANDRADE, J. C.; CANTARELLA, H.; QUAGGIO, J. A. Análise química para avaliação da fertilidade de solos tropicais. Campinas: Instituto Agronômico, 2001. 285 p.
SANTOS, M. E. R.; FONSECA, D. M.; BALBINO, E. M.; MONNERAT, J. P.; SILVA, S. P. Caracterização de perfilhos em pastos de capim-braquiária diferidos e adubados com nitrogênio. Revista Brasileira de Zootecnia, Viçosa, MG, v. 38, n. 4, p. 643-649, 2009.

SILVA, R. V. M. M.; ROSSIELLO, R. O. P.; MORENZ, M. J. F.; BARBIERI JUNIOR, É.; GOMES, R. L. T. Uso de clorofilometro na avaliação da adubação nitrogenada e potássica no capim Tifton 85. Revista Brasileira de Saúde e Produção Animal, Salvador, v. 12, n. 3, p. 828839, 2011.

SILVA, S. C. da; NASCIMENTO JÚNIOR, D.; EUCLIDES, V. B. P. Pastagens: conceitos básicos, produção e manejo. Viçosa, MG: Suprema, 2008. 115 p.

SILVEIRA, C. P. Doses de nitrogênio e de enxofre para a recuperação de pastagem com capim-braquiária: atributos de parte aérea, raizes e fertilidade do solo. 2009. Tese (Doutorado em Agronomia) - Escola Superior de Agricultura Luiz de Queiroz, Universidade de São Paulo, Piracicaba.

SISTEMA PARA ANÁLISES ESTATÍSTICAS - SAEG. versão 9. 1. Viçosa, MG: Fundação Arthur Bernardes, UFV, 2007.

TEIXEIRA, F. A.; BONOMO, P.; PIRES, A. J. V.; SILVA, F. F.; FRIES, D. D.; HORA, D. S. Produção anual e qualidade de pastagem de Brachiaria decumbens diferida e estratégias de adubação nitrogenada. Acta Scientiarum. Animal Sciences, Maringá, v. 33, n. 3, p. 241-248, 2011.

VIANA, M. C. M.; FREIRE, F. M.; FERREIRA, J. J.; MACÊDO, G. A. R.; CANTARUTTI, R. B.; MASCARENHAS, M. H. T. Adubação nitrogenada na produção e composição química do capim-braquiária sob pastejo rotacionado. Revista Brasileira de Zootecnia, Viçosa, MG, v. 40, n. 7, p. 1497-1503, 2011.

UNIVERSIDADE FEDERAL DE VIÇOSA - UFV. SAEG - Sistema de análises estatísticas e genéticas. versão 9. 1. Viçosa, MG: Fundação Arthur Bernardes, UFV, 2007.

VITOR, C. M. T.; FONSECA, D. M.; CÓSER, A. C.; MARTINS, C. E.; NASCIMENTO JÚNIOR, D.; RIBEIRO JÚNIOR, J. I. Produção de matéria seca e valor nutritivo de pastagem de capim-elefante sob irrigação e adubação nitrogenada. Revista Brasileira de Zootecnia, Viçosa, MG, v. 38, n. 3, p. 435-442, 2009.

ZOTARELLI, L.; CARDOSO, E. G.; PICCININ, J. L.; URQUIAGA, S.; BODDEY, R. M.; TORRES, E.; ALVES, B. J. R. Calibração do medidor de clorofila Minolta SPAD-502 para avaliação do conteúdo de nitrogênio no milho. Pesquisa Agropecuária Brasileira, Brasília, v. 38, n 9, p. 1117-1122, 2003. 